\title{
MAJOR ELEMENT CONCENTRATIONS IN MANGROVE PORE WATER, SEPETIBA BAY, BRAZIL
}

\author{
Christian J. Sanders ${ }^{*}$, Renato G. S. Barcellos and Emmanoel V. Silva-Filho
}

Universidade Federal Fluminense

Instituto de Química - Departamento de Geoquímica

Rua Otávio João Baptista S/N, Morro do Valonginho Niterói-RJ, Brasil 24020-141

*Corresponding author: zinosanders@yahoo.com

\section{A B S T R ACT}

Concentrations of cations and anions of major elements $\left(\mathrm{Na}^{+}, \mathrm{Ca}^{2+}, \mathrm{Mg}^{2+}, \mathrm{K}^{+}, \mathrm{Cl}^{-}, \mathrm{SO}_{4}{ }^{2-}\right)$ were analyzed in the pore water of a mangrove habitat. Site specific major element concentrations were identified along a four piezometric well transect, which were placed in distinct geobotanic facies. Evapotranspiration was evident in the apicum station, given the high salinity and major element concentrations. The station landward of an apicum was where major element/ $\mathrm{Cl}^{-}$ratios standard deviations are greatest, suggesting intense in situ diagenesis. Molar ratios in the most continental station (4) are significantly lower than the nearby freshwater source, indicating a strong influence of sea water flux into the outer reaches of the mangrove ecosystem and encroaching on the Atlantic rain forest. Indeed, the $\mathrm{SO}_{4}{ }^{2-} / \mathrm{Cl}^{-}$and $\mathrm{Ca}^{2+} / \mathrm{Cl}^{-}$ratios suggest limited $\mathrm{SO}_{4}{ }^{2-}$ reduction and relatively high $\mathrm{Ca}^{2+} / \mathrm{Cl}^{-}$ratios indicate a region of recent saltwater contact.

\section{RESUMO}

As concentrações dos elementos maiores $\left(\mathrm{Na}^{+}, \mathrm{Ca}^{2+}, \mathrm{Mg}^{2+}, \mathrm{K}^{+}, \mathrm{Cl}^{-}, \mathrm{SO}_{4}{ }^{2-}\right)$ foram analisadas na água intersticial de poços piezométricos localizados em diferentes fácies geobotânicas ao longo de um transecto num ecossistema de manguezal na Baía de Sepetiba - Rio de Janeiro. Maiores salinidades e concentrações dos íons maiores são evidencias de evapotranspiração no fácies apicum. Ainda no apicum foram observados os maiores desvios padrão da razão elemento/ $\mathrm{Cl}^{-}$durante o período do estudo, indicando intensa diagênese in situ. Razões molares no piezômetro, localizado na borda do manguezal foram consideravelmente menores do que a fonte de água doce, indicando forte influência do fluxo de água marinha. Os resultados das razões molares, $\mathrm{SO}_{4}{ }^{2-} / \mathrm{Cl}^{-}$e $\mathrm{Ca}^{2+} / \mathrm{Cl}^{-}$na borda do manguezal adjacente ao continente sugerem limitada redução de $\mathrm{SO}_{4}{ }^{2-}$ enquanto os valores relativamente altos na razão $\mathrm{Ca}^{2+} / \mathrm{Cl}^{-}$indicam contacto recente com água marinha.

Descriptors: Evapotranspiration, Groundwater, Major element/Cl ratio, Diagenesis.

Descritores: Evapotranspiração, Água intersticial, Razão elemento principal/Cl, Diagênese.

\section{INTRODUCTION}

Fluid inclusions are used regularly to gain insight on composition of wetland pore water in a wide range of geological environments (SHEPHERD et al., 2000), including mangrove ecosystems (Ridd and Stieglitz, 2002). Elevated concentrations of major element $\left(\mathrm{Cl}^{-}, \mathrm{SO}_{4}{ }^{2-}, \mathrm{Na}^{+}, \mathrm{K}^{+}, \mathrm{Mg}^{2+}\right.$, and $\left.\mathrm{Ca}^{2+}\right)$ may be brought about by diagenetic reactions in mangrove ecosystems, where fresh water and sea water interact (SILVA-FILHO et al., 2009). Such geochemical reactions may be heightened in tropical coastal systems where mangrove forests may increase salinity of shallow pore water through extensive evapotranspiration, as salinity commonly increases beyond sea water values (MCGOWAN; MARTIN, 2007). The relationships between submarine groundwater discharge, relative sea level rise and diagenetic reactions in coastal wetlands have been documented (MOORE, 1999; SILVA-FILHO et al., 2009; SOTO-JIMÉNEZ; PÁEZ-OSUNA， 2010). Major element concentrations of cations and anions may be used to indicate the mixing among water masses and water source.

As chloride is conservative in most diagenetic and biological reactions, the ratio of this element with other solutes, e.g., major element $/ \mathrm{Cl}^{-}$ ratios, may be used to define subtle changes in water composition, indicative of a changing source (RAO et al., 2009 ). The aim of this manuscript is to evaluate the ability of major element/Cl- ratios in pore water along a transection within mangrove zones, indicative of source. We propose the use of major element/Clratios in pore water, directly influenced by specific geochemical processes taking place within a zone where fresh pore water and sea water interact. 


\section{Study Area}

Sepetiba Bay is being located at longitude $44^{\circ} \mathrm{W}$; latitude $23^{\circ} \mathrm{S}$, near Rio de Janeiro, city (Fig. 1). The bay is approximately $305 \mathrm{~km}^{2}$ and extends $40 \mathrm{~km}$ from east to west and $20 \mathrm{~km}$ from north to south. The drainage basin has catchments of $2617 \mathrm{~km}^{2}$ with 22

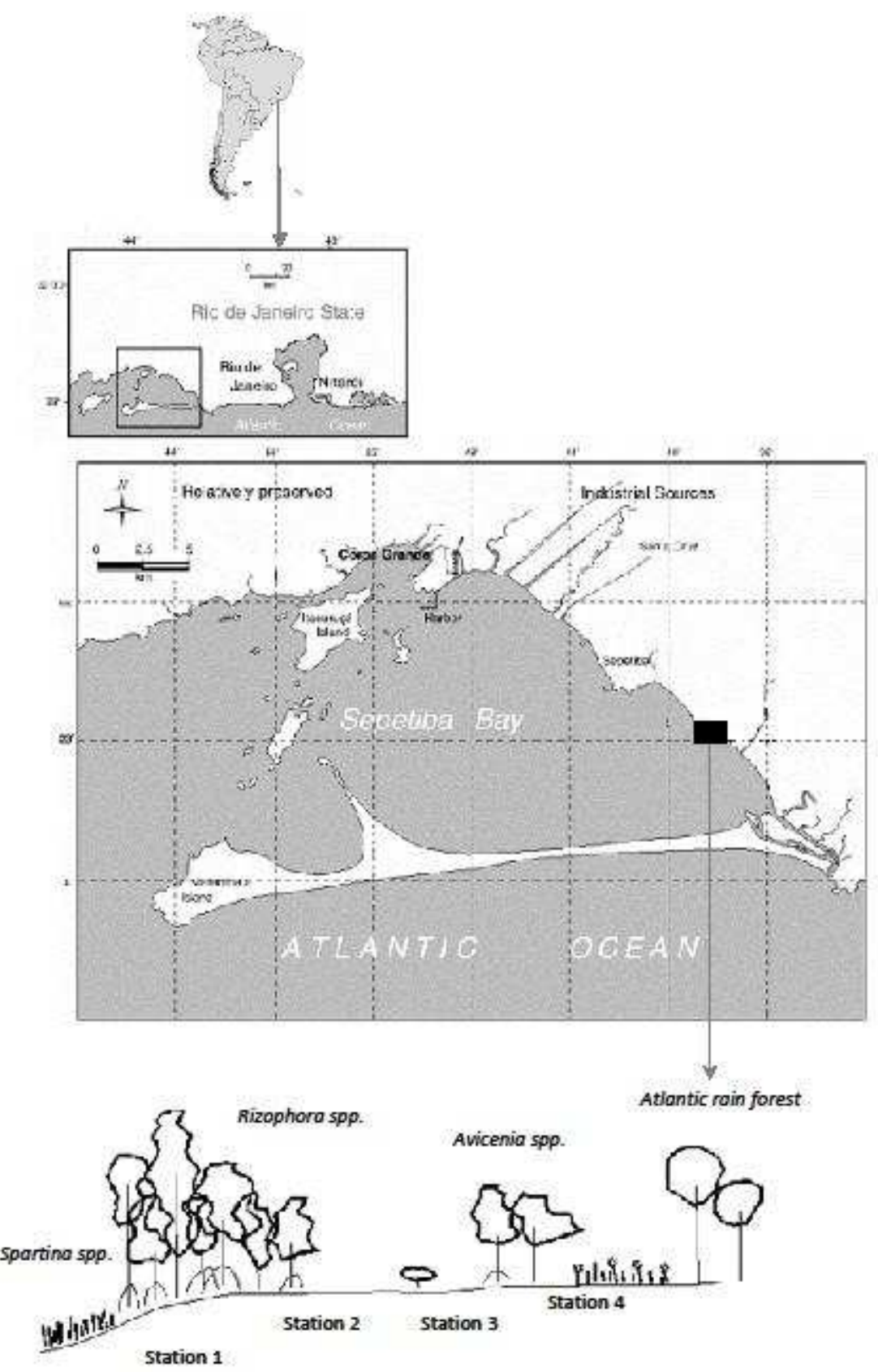

separate sub-watersheds. The region is under a hothumid tropical limit with the mean annual precipitation ranging from $1400 \mathrm{~mm}$ to $2500 \mathrm{~mm}$. The bay is surrounded by mangrove forests where environmental preservation and urban areas correspond to $20 \%$ and $9.2 \%$ of the catchments, respectively. 


\section{Material and Methods}

The study area is located in Brisa Beach, Environmental Protected Area of Sepetiba Bay, Brazil (Fig. 1). To determine the processes associated with dissolved major element/Cl- ratios, yearlong sampling was undertaken in wells along a four station mangrove transect. The four sampling stations were across differing mangrove zones: (1) lower tidal flat, characterized by external mangrove vegetation (i.e. at the edge of the coast, lined with Spartina spp. and Rhizophora spp.) (2) upper tidal flat, characterized by a hypersaline, unvegetaded apicum zone, (3) internal mangrove, mainly composed of Avicenia spp, near the spring high tide limit and (4) inland zone, characterized by a grass plain followed by Avicenia spp. The horizontal distances between stations were 30 $\mathrm{m}$. Fresh river water and sea water were also collected near the study site throughout the year and analyzed in the same batch as the samples taken from the wells.

Water samples were collected at each station from piezometers wells between January an December of 2003. The PVC piezometric wells were covered by the $63 \mu \mathrm{m}$ membrane, to prevent suspended material from entering the wells, and inserted to a two meter depth. The water samples were collected from the piezometric wells using $3 \mathrm{~m}$ long tubes and syringes to extract the pore water. The $\mathrm{pH}$ values were determined using a OAKTON probe. Salinity was determined during each field trip with hand-held YSI sensor. The samples were filtered in situ onto a $45 \mu \mathrm{m}$ filter (GFC glass fiber) and were stored in $60 \mathrm{ml}$ polyethylene bottles, transported to the laboratory in a cool box and stored at fridge temperature $\left(4^{\circ} \mathrm{C}\right)$ until analyses. The major element concentrations were determined by an ionic chromatography (SHIMADZU LC-10AD). Precision was determined by measuring a standard after every tenth sample and assessed by calculating the coefficient of variation (standard deviation divided by the average value). The coefficients of the variation were $\sim 1 \%$ for $\mathrm{Na}^{+}$and $\mathrm{Mg}^{2+}$ and $\sim 2 \%$ for $\mathrm{K}^{+}$, and $\mathrm{Ca}^{2+}$ concentrations.

\section{Results}

To define the study area of this work as a mixing zone, a fresh water endmember was established by taking river samples. As sea water values vary little, multiple sampling was deemed unnecessary. The endmember results represent the perspective extreme values of the water masses coming into contact within the region where fresh pore water and sea water meet. The endmember concentrations measured in this study were in agreement with local fresh water and sea water values (Tables 1 and 2). Major element concentrations $\left(\mathrm{Na}^{+}, \mathrm{Ca}^{2+}, \mathrm{Mg}^{2+}, \mathrm{K}^{+}, \mathrm{Cl}^{-}, \mathrm{SO}_{4}{ }^{2-}\right), \mathrm{pH}$ and salinity are shown on Table 1. Both cation and anion concentrations are greatest in station 2 where salinity is greatest. In fact the major element concentrations $\left(\mathrm{Na}^{+}, \mathrm{Ca}^{2+}, \mathrm{Mg}^{2+}, \mathrm{K}^{+}, \mathrm{Cl}^{-}, \mathrm{SO}_{4}{ }^{2-}\right)$ are significantly controlled by salinity, the statistics related to the 12 month campaign are as follow: $\left(\mathrm{Na}^{1+}, \mathrm{y}=16.0+3.7\right.$, $\left.\mathrm{r}^{2}=0.98, \mathrm{n}=31, \mathrm{p}<0.05\right)\left(\mathrm{Ca}^{2+}, \mathrm{y}=0.22 \mathrm{x}+10.3, \mathrm{n}=\right.$ $\left.31, \mathrm{r}^{2}=0.66, \mathrm{p}<0.05\right)\left(\mathrm{Mg}^{2+}, \mathrm{y}=1.7 \mathrm{x}+1.6, \mathrm{r}^{2}=\right.$ $0.66, \mathrm{n}=31, \mathrm{p}<0.05)\left(\mathrm{K}^{1+}, \mathrm{y}=0.38 \mathrm{x}+0.24, \mathrm{r}^{2}=0.80\right.$, $\mathrm{n}=31, \mathrm{p}<0.05)\left(\mathrm{Cl}^{-}, \mathrm{y}=17.0 \mathrm{x}+17.7, \mathrm{r}^{2}=0.98, \mathrm{n}=\right.$ $31, \mathrm{p}<0.05)\left(\mathrm{SO}_{4}{ }^{2+}, \mathrm{y}=1.0 \mathrm{x}+0.17, \mathrm{r}^{2}=0.91, \mathrm{n}=31\right.$, $\mathrm{p}<0.05)$. The average salinity varied greatly between stations $1,2,3$, and 4 (42.80, 65.73, 5.25 and 6.66, respectively). When average elemental concentrations are normalized by $\mathrm{Cl}^{-}$(element/ $\mathrm{Cl}^{-}$), results appear to be generally conservative for specific elements $\left(\mathrm{Na}^{1+}\right.$ $\left.\mathrm{Ca}^{2+} \mathrm{K}^{1+}\right)$ along the four station $(\mathrm{n}=4)$ of the transect: $\mathrm{Na}^{1+} / \mathrm{Cl}^{-}\left(\mathrm{r}^{2}=0.85\right) ; \mathrm{Ca}^{2+} / \mathrm{Cl}^{-1}\left(\mathrm{r}^{2}=0.80\right) ; \mathrm{Mg} 2^{+} / \mathrm{Cl}^{-}\left(\mathrm{r}^{2}\right.$ $=0.23) ; \mathrm{K}^{1+} / \mathrm{Cl}^{-}\left(\mathrm{r}^{2}=0.69\right) ; \mathrm{SO}_{4}{ }^{2+} / \mathrm{Cl}^{-}\left(\mathrm{r}^{2}=0.28\right)$. Specific spacial values worth noting are the $\mathrm{Ca}^{2+} / \mathrm{Cl}^{-}$ and $\mathrm{SO}_{4}{ }^{2-+} / \mathrm{Cl}^{-}$ratios in station 4 , being generally higher than the other stations (Fig. 2). In terms of the year long sampling, the major element $/ \mathrm{Cl}^{-}$ratio averages varied greatest in station 3 , excluding $\mathrm{SO}_{4}{ }^{2-}$ $/ \mathrm{Cl}^{-}$in station 4 (Table 2). As mentioned above, station 2 showed the highest salinities, increasing up to twice to that of sea water.

\section{Discussion}

The major element concentrations and element $/ \mathrm{Cl}^{-}$ratios found along the intertidal gradient are comparable to the values found in Silva-Filho et al., (2009) and McGowan and Martin (2007). Excluding $\mathrm{Ca}^{2+} / \mathrm{Cl}^{-}$and $\mathrm{SO}_{4}{ }^{2-+} / \mathrm{Cl}^{-}$, specific ratios along the study area are distinctly similar. In contrast, major element concentrations $\left(\mathrm{Na}^{+}, \mathrm{Ca}^{2+}, \mathrm{Mg}^{2+}, \mathrm{K}^{+}, \mathrm{Cl}^{-}\right.$, $\mathrm{SO}_{4}{ }^{2-}$ ) show differing distribution gradients, having site specific elemental signatures significantly influenced by salinity (Fig. 2). The high salinities and major element concentrations found in station 2 correspond to the the open areas within the apicum, suggesting active evapotranspiration in this intertidal region of the mangrove ecosystem. From the molar ratios and concentrations measured in the four stations along the year, are for the most part, considerably lower than values found in nearby river water (Table 1 and 2). Considering the ocean water endmember, these values indicate a strong influence of sea water flux into the mangrove ecosystem pore water, even in the outer limits of the tidal flat where salinity is relatively low. The relatively high salinity in the pore water from within the intertidal region, specifically in station 2, and levels of major element concentrations of cations and anions $\left(\mathrm{Na}^{+}, \mathrm{Ca}^{2+}, \mathrm{Mg}^{2+}, \mathrm{K}^{+}, \mathrm{Cl}^{-}, \mathrm{SO}_{4}{ }^{2-}\right)$, are indicative of saltwater intrusion into the mangrove pore water (SILVA-FILHO et al., 2009 ). 
Table 1. The results obtained for salinity $\mathrm{pH}$ and the 6 major elements analyzed in the four stations through monthly samplings over a year. Sea water reference values are also presented.

\begin{tabular}{|c|c|c|c|c|c|c|c|c|c|}
\hline Station & $\begin{array}{l}\text { Date } \\
2003\end{array}$ & salinity & $\overline{\mathrm{pH}}$ & $\begin{array}{l}\mathrm{Ca}^{2+} \\
\mathrm{mM}\end{array}$ & $\begin{array}{c}\mathrm{Mg}^{2+} \\
\mathrm{mM}\end{array}$ & $\begin{array}{l}\mathrm{Na}^{+} \\
\mathrm{mM}\end{array}$ & $\begin{array}{c}\mathrm{K}^{+} \\
\mathrm{mM}\end{array}$ & $\begin{array}{c}\mathrm{Cl}^{-} \\
\mathrm{mM}\end{array}$ & $\begin{array}{c}\mathrm{SO}_{4}{ }^{2-} \\
\mathrm{mM}\end{array}$ \\
\hline \multirow{10}{*}{1} & jan & 40 & 8.19 & 19.1 & 79.3 & 664.7 & 25.7 & 732.1 & 40.5 \\
\hline & fev & 40 & 7.26 & 18.0 & 72.2 & 736.9 & 24.9 & 850.2 & 35.8 \\
\hline & mar & 50 & 7.91 & 18.2 & 72.2 & 704.3 & 25.7 & 857.7 & 43.6 \\
\hline & abr & 45 & 7.61 & 18.2 & 70.3 & 742.4 & 13.9 & 790.6 & 45.9 \\
\hline & mai & 40 & $* \mathrm{NA}$ & 19.2 & 71.1 & 657.8 & 13.7 & 769.3 & 46.6 \\
\hline & jun & 46 & 6.91 & 18.4 & 68.9 & 733.7 & 13.5 & 841.4 & 40.2 \\
\hline & ago & 46 & 7.28 & 18.0 & 68.2 & 813.4 & 19.0 & 841.7 & 33.6 \\
\hline & out & 36 & 6.89 & 17.0 & 59.9 & 740.0 & 17.6 & 778.3 & 38.7 \\
\hline & nov & 37 & 6.89 & 17.4 & 64.1 & 733.1 & 18.1 & 829.0 & 28.0 \\
\hline & dez & $* \mathrm{NA}$ & $* \mathrm{NA}$ & 18.0 & 68.0 & 735.1 & 18.6 & 789.6 & 30.1 \\
\hline \multirow{10}{*}{2} & jan & 60 & 7.93 & 26.1 & 126.9 & 981.2 & 31.4 & 1136.2 & 70.6 \\
\hline & fev & 63 & 6.85 & 24.4 & 108.7 & 1060.3 & 29.9 & 1132.3 & 97.4 \\
\hline & $\operatorname{mar}$ & 68 & 6.37 & 25.0 & 119.8 & 1093.0 & 31.4 & 1156.6 & 61.3 \\
\hline & abr & 63 & 7.1 & 26.8 & 109.9 & 1044.2 & 16.9 & 1225.1 & 77.3 \\
\hline & mai & 70 & 7.42 & 25.9 & 110.9 & 988.4 & 16.6 & 1162.5 & 67.1 \\
\hline & jun & 70 & 7.00 & 29.3 & 110.8 & 975.9 & 16.6 & 1060.5 & 63.5 \\
\hline & ago & 70 & 7.00 & 25.6 & 106.5 & 1096.2 & 22.0 & 1191.1 & 61.7 \\
\hline & out & 63 & 6.56 & 27.4 & 115.1 & 982.7 & 22.0 & 1185.9 & 63.6 \\
\hline & nov & 65 & 6.7 & 24.8 & 119.4 & 1083.0 & 27.3 & 1288.3 & 67.0 \\
\hline & dez & $* \mathrm{NA}$ & $* \mathrm{NA}$ & 25.3 & 113.6 & 1071.5 & 22.3 & 1116.6 & 67.9 \\
\hline \multirow{10}{*}{3} & jan & 4 & $* \mathrm{NA}$ & 0.0 & 30.0 & 224.4 & 8.6 & 244.4 & 8.0 \\
\hline & fev & 5 & 7.74 & 3.0 & 6.0 & 53.5 & 1.4 & 64.9 & 2.8 \\
\hline & $\operatorname{mar}$ & 10 & 7.3 & 11.2 & 21.4 & 88.1 & 5.0 & 150.7 & 5.9 \\
\hline & $a b r$ & 6 & 7.37 & 6.4 & 10.9 & 77.0 & 1.2 & 97.4 & 3.8 \\
\hline & mai & 3 & 7.82 & 2.7 & 5.1 & 51.6 & 0.3 & 63.6 & 1.8 \\
\hline & jun & 2 & 7.8 & 1.3 & 2.6 & 25.1 & 1.3 & 29.5 & 1.2 \\
\hline & ago & 7 & *NA & *NA & *NA & *NA & *NA & $* \mathrm{NA}$ & $* \mathrm{NA}$ \\
\hline & out & 4 & 7.13 & 8.4 & 12.6 & 127.2 & 2.7 & 157.5 & 6.5 \\
\hline & nov & $* \mathrm{NA}$ & $* \mathrm{NA}$ & $* \mathrm{NA}$ & 1.9 & 32.8 & 0.9 & 34.0 & 1.1 \\
\hline & dez & $* \mathrm{NA}$ & $* \mathrm{NA}$ & $* \mathrm{NA}$ & $*$ NA & $* N A$ & *NA & $* \mathrm{NA}$ & $* \mathrm{NA}$ \\
\hline \multirow{10}{*}{4} & jan & 8 & 8.12 & 19.3 & 12.6 & 102.1 & 1.9 & 133.5 & 9.9 \\
\hline & fev & 7 & 6.91 & 16.6 & 8.8 & 99.8 & 1.4 & 124.7 & 8.5 \\
\hline & $\operatorname{mar}$ & 7 & $* \mathrm{NA}$ & *NA & $* \mathrm{NA}$ & *NA & $* \mathrm{NA}$ & $* \mathrm{NA}$ & $* \mathrm{NA}$ \\
\hline & abr & 7 & 7.37 & 16.0 & 7.2 & 81.8 & 1.2 & 112.4 & 8.8 \\
\hline & mai & 7 & 7.39 & 16.9 & 7.4 & 89.0 & 1.2 & 119.3 & 8.8 \\
\hline & jun & 7 & 6.9 & 17.8 & 7.9 & 92.8 & 1.2 & 125.6 & 11.1 \\
\hline & ago & 6 & 6.9 & 14.5 & 6.3 & 95.4 & 0.9 & 117.5 & 8.8 \\
\hline & out & 8 & 6.57 & 15.8 & 6.6 & 103.3 & 1.0 & 123.7 & 8.4 \\
\hline & nov & 6 & 9.03 & 19.9 & 9.0 & 98.2 & 1.3 & 132.2 & 12.1 \\
\hline & dez & 7 & $* \mathrm{NA}$ & 20.9 & 10.4 & 99.0 & 1.4 & 130.1 & 10.1 \\
\hline Sea & & 34 & 8.89 & 10.1 & 47.0 & 451.8 & 8.8 & 544.3 & 19.7 \\
\hline
\end{tabular}

*NA - data not available

Table 2. Average major element/ $\mathrm{Cl}^{-}$ratios and the standard deviatiaons ( $\mathrm{N}$ between 7 and 10) in the four study stations and in the freshwater and ocean water endmember values. Ocean water chemical composition was consistant therefore standard deviations are not shown.

\begin{tabular}{ccccccccccc}
\hline \hline point & $\mathrm{Ca}^{2+} / \mathrm{Cl}^{-}$ & Stdev & $\mathrm{Mg}^{2+} / \mathrm{Cl}^{-}$ & stdev & $\mathrm{Na}^{1+} / \mathrm{Cl}^{-}$ & stdev & $\mathrm{K}^{1+} / \mathrm{Cl}^{-}$ & stdev & $\mathrm{SO}_{4}^{2+} / \mathrm{Cl}^{-}$ & stdev \\
\hline 1 & 0.022 & 0.002 & 0.086 & 0.009 & 0.899 & 0.045 & 0.024 & 0.006 & 0.047 & 0.009 \\
2 & 0.022 & 0.002 & 0.098 & 0.007 & 0.891 & 0.049 & 0.020 & 0.005 & 0.060 & 0.010 \\
3 & 0.054 & 0.013 & 0.099 & 0.024 & 0.779 & 0.097 & 0.022 & 0.014 & 0.039 & 0.005 \\
4 & 0.141 & 0.011 & 0.068 & 0.013 & 0.770 & 0.037 & 0.010 & 0.002 & 0.077 & 0.008 \\
river & 0.278 & 0.070 & 0.160 & 0.022 & 1.180 & 0.221 & 0.057 & 0.037 & 0.070 & 0.024 \\
ocean & 0.019 & & 0.086 & & 0.830 & & 0.016 & & 0.036 \\
\hline
\end{tabular}



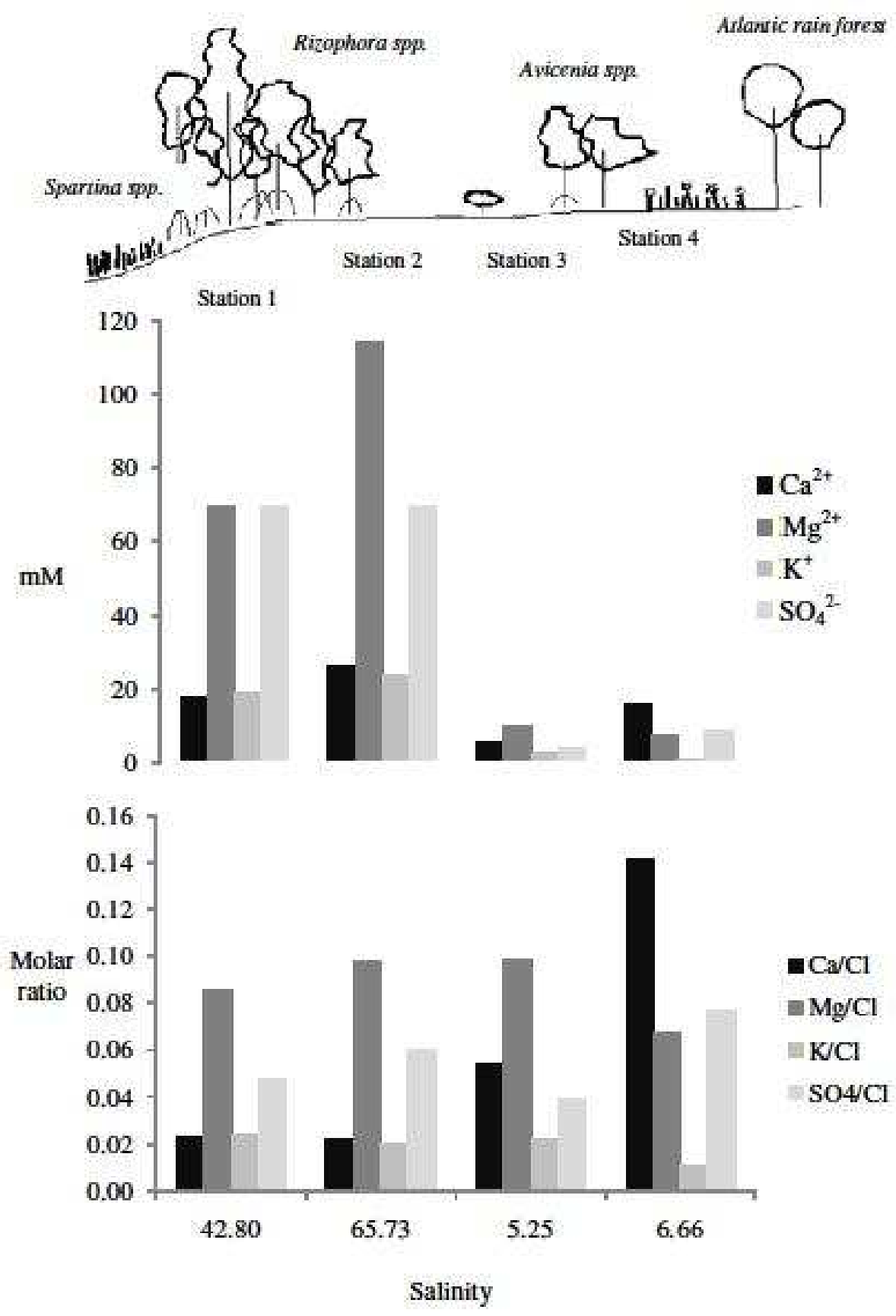

Fig. 2. Average major element concentrations (excluding $\mathrm{Cl}$ and $\mathrm{Na}$ ) against average salinity values from the four studied stations.

The site specific salinity variations indicate a differing sea water intensity within the pore water of each zone, likely triggering geochemical processes along this intertidal system. The high salinities in station 2 demonstrate that some of the saline water is stagnant and exposed to evapotranspiration. To determine the mass fluxes associated to specific major element concentratiaons, it is important to understand the mechanisms that could alter the composition of the pore water, likely discharging into the Sepetiba Bay as recirculating groundwater (MOORE, 2008). This is because geochemical processes within this mixing 
zone may alter the pore water composition (SANTOS et al., 2008), which is of interest, particularly because pore water discharge to Sepetiba Bay has been reported to be considerably high (SMOAK et al., 2006). Besides salinity, sea water $\mathrm{pH}$ may also play a role in the cation and anion concentrations in the stations of this study (Table 1) (MCGOWAN; MARTIN, 2007). Given the relationship between cation and anion concentrations, there appears to be no relation between major element/Cl ${ }^{-}$ratios and salinity (Fig. 2). Plots of the major element/ $\mathrm{Cl}^{-}$ratios indicate that the four sites are directly influenced by the geochemical reactions of sea water intrusion, even beyond the outer limits of the tidal flat.

Station 3 is located in an area with the lowest mean saltwater concentration and is the site with the greatest major element/Cl- standard deviations, varying significantly throughout the year. The concentrations and molar ratios variations along the year probably reflect intense in situ diagenesis brought about through tidal pumping and/or local sea level rise, as station 3 is likely on the front where fresh pore water and sea water mix, as indicated by the oscillating low salinities. (Fig. 2)

Station 4 , where the $\mathrm{Ca}^{2+} / \mathrm{Cl}^{-}$ratios show relatively high values, resembling a possible stagnant region on the edge of the mangrove ecosystem, or an area of reduced groundwater inflow. As none of the stations exhibit $\mathrm{SO}_{4}{ }^{2-} / \mathrm{Cl}^{-}$ratios below the average ratio obtained for sea water values (Table 2), suggesting limited $\mathrm{SO}_{4}{ }^{2-}$ reduction in station 4 sediment. Some $\mathrm{SO}_{4}{ }^{2-}$ reduction should occur within the sediment due to the sulfide present in the pore water (MCGOWAN; MARTIN, 2007). The high $\mathrm{SO}_{4}{ }^{2-} / \mathrm{Cl}^{-}$ratios may reflect reducing conditions and metal sulfides in solution. Indeed, in station 4 the $\mathrm{SO}_{4}{ }^{2-} / \mathrm{Cl}^{-}$molar ratios are higher than both ocean and river endmembers, strengthening the argument of stagnant pore water or reduced groundwater inflow at this site. Considering the salinity and average pore water molar ratios of $\mathrm{Ca}^{2+} / \mathrm{Cl}^{-}$and $\mathrm{SO}_{4}{ }^{2-} / \mathrm{Cl}^{-}$, station 4 may represent a region of recent saltwater contact.

The assumptions made is this work are supported by studies indicating that Sepetiba Bay is influenced by large ground water discharge (SMOAK et al., 2006), deterimened from $\mathrm{Ra}$ mass balance calculations, as well undergoing a relative rising sea level (SANDERS et al., 2008; SMOAK ; PATCHINEELAM, 1999), as indicated through sediment accumulation rates in nearby mangrove forests. As mangrove forests are migrating inland near the study site of this work, studies have indicated sea water intrusion into mangrove forests during the previous decade (SOARES et al, 2000; SOARES, 2011). While mangrove forest migration indicates relative sea level rise in Sepetiba Bay, the data in this study demonstrates some of the bellow ground geochemical processes associated to salt water intrusion in mangrove pore water. As there is a lack of studies dealing with pore water geochemistry in mangrove habitats, there is a limited amount of literature available for comparative purposes. The results of this study provide an outline for future studies on some of the geochemical processes controlling pore water chemistry in (sub) tropical coastal wetlands where mangroves are prevalent.

\section{Conclusion}

Considering the river water and ocean water endmembers, the element $/ \mathrm{Cl}^{-}$ratios are indicative of sea water flow into the mangrove pore water, even beyond the outer limits of the tidal flat. From the station furthest inland (station 4), the $\mathrm{SO}_{4}{ }_{4}^{2-} / \mathrm{Cl}^{-}$and $\mathrm{Ca}^{2+} / \mathrm{Cl}^{-}$ratios suggest limited $\mathrm{SO}_{4}{ }^{2-}$ reduction and relatively high $\mathrm{Ca}^{2+} / \mathrm{Cl}^{-}$ratios which likely indicate stagnant waters or reduced groundwater inflow in a region of recent saltwater contact. The oscillating low salinities in stations 3 and the $\mathrm{SO}_{4}{ }^{2-} / \mathrm{Cl}^{-}$and $\mathrm{Ca}^{2+} / \mathrm{Cl}^{-}$ ratios in station 4 are likely caused by the relative sea level rise previously reported in the study area. The results of this study show some of the geochemical processes, such as evapotranspiration and diagenesis, control pore water chemistry in (sub)tropoical coastal wetlands where mangroves are prevalent. The processes that govern changes in the chemical composition of the pore water may be indicative of the sea water intrusion, as shown by the element $/ \mathrm{Cl}^{-}$ geochemical tracers outlined in this study.

\section{ACKNOWLEDGEMENTS}

This work is part of the Instituto do Milênio (CNPq/420050/2005-1) and INCT-TMCOcean (573601/2008-9). Christian J. Sanders thanks CAPES and FAPERJ, Grant (E-26/101.952/2009).

\section{REFERENCES}

MCGOWAN, K. T.; MARTIN, J. B. Chemical composition of mangrove-generated brines in Bishop Harbor, Florida: Interactions with submarine groundwater discharge. Mar. Chem., v. 104, p. 58-68, 2007.

MOORE, W. S. The subterranean estuary: a reaction zone of ground water and sea water. Mar. Chem., v. 65, p. 111$125,1999$.

MOORE, W. S. Fifteen years experience in measuring ${ }^{224} \mathrm{Ra}$ and ${ }^{223} \mathrm{Ra}$ by delayed-coincidence counting. Mar. Chem., v. 109, p. 188-197, 2008.

$\mathrm{RAO}, \mathrm{M}$. N. et al. Fluid-evaporation records preserved in salt assemblages in Meridiani rocks. Earth planet. Sci. Letts, v. 286, p. 396-403, 2009. 
RIDD, P.V.; STIEGLITZ, T. Dry season salinity changes in arid estuaries fringed by mangroves and saltflats. Estuar. coast Shelf Sci., v. 54, p. 1039-1049, 2002.

SANDERS, C. J.; SMOAK, J. M.; NAIDU, A. S.; PATCHINEELAM, S. R. Recent sediment accumulation in a mangrove forest and its relevance to local sea level rise (Ilha Grande, Brazil). J. coast. Res., v. 24, n. 2, p. 533-536, 2008.

SANTOS, I. R., et al. Nutrient biogeochemistry in a Gulf of Mexico subterranean estuary and groundwater derived fluxes to the coastal ocean. Limn. Ocean., v. 53 n.2, p. $705-718,2008$

SHEPHERD, T. J.; NADEN, J.; CHENERY, S. R. ; MILODOWSKI, A. E. ; GILLESPIE, M. R. Chemical analysis of palaeogroundwaters: a new frontier for fluid inclusion research. J. geochem. Explor., v. 69-70 p. 415-418, 2000.

SILVA-FILHO, E. V. et al. Groundwater chemical characterization of a Rio de Janeiro coastal aquifer, SE Brazil. J. South American Earth Sci., v. 27, p. 100 108, 2009.

SMOAK, J.; SANDERS, C. J.; MOORE, W. S.; GODOY, J. M.; PATCHINEELAM, S. R. Large submarine groundwater inputs to Sepetiba Bay, Rio de Janeiro State, Brazil. In: AGU FALL MEETING, San Fransisco, Ca, 2006.
SMOAK, J. M.; PATCHINEELAM S. R. Mangroves Salt Marshes,v. 3, p. 17, 1999.

SOARES, M. L. G. Reflexos das alterações climáticas sobre o ecossistema manguezal. In: CONGRESSO LATINOAMERICANO DE CIENCIAS DO MAR, 14. Balneario Camboriu, SC, Brazil, 2011.

SOARES, M. L. G.; SCHAEFFER-NOVELLI, Y.; CINTRON-MOLERO,G. The use of mangroves as indicators of sea-level changes. In: INTERNATIONAL WETLAND SYMPOSIUM, 6. INTERNATIONAL ASSOCIATION OF ECOLOGY. MILLENNIUM WETLAND EVENT, Quebec, Canada, 2000. p. 213.

SOTO-JIMÉNEZ, M. F.; PÁEZ-OSUNA, F. A first approach to study the mobility and behavior of lead in hypersaline salt marsh sediments: Diffusive and advective fluxes, geochemical partitioning and $\mathrm{Pb}$ isotopes. J. geochem. Explor., v. 104, p. 87-96, 2010.

(Manuscript received 10 August 2011; revised 22 November 2011; accepted 03 February 2012) 